Research Article DOI: https://doi.org/10.47434/JEREDA.

eISSN : 2735-9107

\title{
FUNDING OPTIONS IN THE MANAGEMENT OF JUNIOR SECONDARY SCHOOLS IN KADUNA STATE, NIGERIA
}

\section{Theresa Stephen Gyang}

Department of Educational Foundations, Faculty of Education, University Of Jos, Nigeria Email: tessysgyang@yahoo.com (iD) https://orcid.org/0000-0001-6957-7527

Received:22 ${ }^{\text {nd }}$ June, 2021; Revised:30th June, 2021; Accepted: $3^{\text {rd }}$ July, 2021

\begin{abstract}
Introduction: Funding education in Nigeria has been challenging. Government has battled synchronous funding shortfalls and has categorically declared that funding education is the responsibility of all. Hence, School leaders are faced with the complex challenges of funding options and managing meagre finances and resources.

Purpose: The objectives of the study were to find out the funding options, determine the management skills used for raising fund, ascertain the contributions of community in funding, and to determine the influence of managerial skills of principals on funding options.
\end{abstract}

Design: Research questions and one null hypothesis were answered and tested to achieve the objectives. The cross-sectional survey design was used. The sample of 111 out of a population of 411 principals was used for the study. A 20 item questionnaire tagged: Funding Options Management Questionnaire (FOMQ) was employed for data collection. The statistical techniques used for analysis are mean and standard deviation for answering research questions and t- test of independence for test of hypothesis.

Results: Findings revealed funding options to include: raising money through the Parents Teachers Association levies, user charges, school-based management charges, alumni assistance with less search for international grants. The managerial skills used to raise fund include cordial relationships, communication, planning, and coordinating. In addition, there was a significant difference between funding options and principals' managerial skills.

Recommendations: It was recommended among others that school administrators should be creative in the funding options, search for international grants, advocate for supports, and government to re-engineer public campaign for awareness and participation of stakeholders in funding education.

Keywords: Funding Options, Management Skills, Junior Secondary, Nigeria.

\section{Cite paper as:}

Crossref Gyang, T. S. (2021). Funding options in the management of junior Cited-by secondary schools in Kaduna state, Nigeria. Journal of Educational Research in Developing Areas, 2 (2), 110-120. https://doi.org/10.47434/JEREDA.2.2.2021.110.

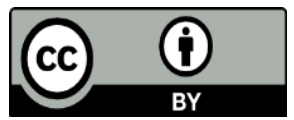

Copyright (c) 2021 The author(s) of this article retain(s) the copyright. 


\section{PUBLIC INTEREST STATEMENT}

The findings of this study will add to the body of knowledge in the aspect of funding options. School leaders will have a deeper knowledge on managerial skills and how to raise fund through PTA, user charges, alumni assistance, community contributions and grants. Government and policy makers will promote use of funding options in schools through sensitization and mobilization of stakeholders. Adequate funding of schools will facilitate quality standard of education.

\section{INTRODUCTION}

The provision of education is capital intensive and requires adequate funding to be able to achieve quality and meet to standard. Education being acclaimed as a veritable tool for measuring the level of development of a nation if underfunded could be detrimental to the growth and development of individuals and the society. It is pathetic that the Nigerian educational system is faced with the dilemma of managing scarce resources due to inadequate funding. Personal observation has shown how junior secondary schools lack the required resources for effective teaching and learning. Consequently, management of the schools appear handicap to addressing the challenges hampering on quality output of the schools.

Education entails all the processes through which an individual acquires knowledge for sustainable development. The Junior Secondary School Education in Nigeria is based in the programme of Universal Basic Education (UBE) in Nigeria, which was launched on the $31^{\text {st }}$ September, 1999 in Sokoto by the then Head of State, General Olusegun Obasanjo. This was triggered by the Clarion call for Education for All (AFA) in a bid to eradicate illiteracy. The major objectives of UBE stated by the Federal Government of Nigeria include; developing in the entire citizenry, a strong consciousness for education and strong commitment to its vigorous promotion; providing a free universal basic education for every Nigerian child of school age irrespective of sex and religion, reducing drastically the incidence of drop-out from the formal school system through improved relevance, quality and efficiency; catering for young persons who for one reason or the other, have had to interrupt their schooling, as well as other out-of-school children and adolescents; ensuring the acquisition of the appropriate level of literacy, numeracy and manipulative, communicative and life skills; and ensuring the acquisition of ethical, moral, and civic values needed for laying a solid foundation for lifelong learning (Federal Ministry of Education, 2014). The UBE programme encompasses the Early Childhood Care and Development Education (ECCDE), 6 years primary education and 3 years junior secondary education and non-formal education. It provides 9 years basic education plus one year ECE making 10 years. It includes all-inclusive educational programmes such as rural and nomadic, urban and slum population, the physically challenged, street children, out-of-school children, the vulnerable and orphans, the migrant fishermen, and adults with special needs.

The implementation of UBE programme by the Federal Government is faced with challenges of funding. Almost every aspect of need is in short supply. A cursory look will show how some schools are dilapidated, classrooms are inadequate where children learn under the trees and sun, shortages of furniture and other teaching and learning materials. The capital-intensive nature of the programme makes it impossible to be free or financed by the Government alone. Other funding options are required to be explored in order to provide effective delivery of the curriculum content, school administration and the realization of school set goals.

Funding option in the educational system is an alternative means of raising fund other than the government financial allocation to education. It involves an initiative for sourcing for finance by the school management from within the 
school and outside the school. Some innovative funding options emanated from the prize targeted at enhancing inventions of the United States of America Presidential Council of Advisors on Science and Technology (PCAST) on University Private Sector Research Partnerships in Innovation Ecosystem released in 2008. This influenced the use of public-private partnership in the funding of education (Olorundare, 2011). It involves the collaboration between the government and the private sector in the process of delivering quality, effective and efficient education. The assumption is for the private sector to strengthen their supply and obtain quality human power, contribute meaningfully in the provision of education to meet the triple bottom line of economic, social and environmental development. Another funding option is the charging of userfees which centres on levies and tuition fees paid by students. Government have set up the Tertiary Education Trust Fund (TETFund), Petroleum Technology Trust Fund (PTDF) to promote funding education (Adamu, 2017; Adida \& Asinde, 2020). Some of the funding options include; Community participation through School Based Management Committee (SBMC), tuition fee, graduate tax, commercializing accommodation, endowment funds, scientific breakthrough, consultancy, part-time programmes, loans, scholarship, taxrelief, Alumni Association Support (AAS), commercialization of products among others. Grants, internally generated revenue, Non-Governmental organizations options, and voluntary support by philanthropist. Okontoni (2014) identify other funding options to include; regular contributions from communities, states, levies on all adults to support schools, local government officials, churches and school authorities. Support from international bodies as the World Bank, UNESCO, UNICEF, UNDP and UNFPA and other financial assistance through bilateral agreement between Nigeria and other countries. Adamu (2017) and Adida and Asindi (2020) noted that user-fees are an integral component of the neo-liberal macro- economic policies put forward within stabilisation and structural adjustment programme (SAP) in Nigeria to facilitate quality management for quality teaching and learning.

Management is crucial in the business of organizing resources and directing its usage through inspirational motivation and intellectual stimulation to detect trends and impact positive changes in the educational sector. Okontoni (2014) defined management as the effective organization and actualization of human and material resources in a particular system. Management involves the means of obtaining and providing money or capital to organization. Fund or money is an important resource needed by schools and management ensures adequate utilization and harnessing of available resources (Man, Money, Materials and Time). School leaders prudent financial management can help in efficiency of allocation of resources, total expenditure and cost effectiveness in production of education.

The identified four types of management skills in any field of management are; related skill, which involves the use of social skills, communication skills, human skills and conceptual skills; technical skill involves the practical knowledge, analytical ability in specialty, the principles and techniques of a task; human relation skill involves creating harmonious working relationship with group members and build cooperative efforts. It is comprised of skills such as; communication, initiating, motivation, interaction and supervising abilities; conceptual skill involves knowing the interrelationship between functions of different units, ability to think and be creative (Mgbolide, 2004; Emenalo, 2009). Effective school leaders use managerial skills to connect with stakeholders, advocate and appeal for financial support and ensure its adequate management for the development of schools. For example, appropriate plans will aid in identifying the problems and setting programme of actions that can be executed to achieve goals, and cordial human relations can facilitate 
understanding between the school and the community which can promote increase contributions to support the school financially and otherwise.

The management of junior secondary schools in Nigeria is inadequate for the deficits experienced in resource allocations. Many graduates of primary school cannot access junior secondary school due to poverty as they cannot afford certain requirements needed to attain school. Despite that basic education was declared free and compulsory in Nigeria; it is challenged of financial inadequacies. Education consumers have to pay the private cost of education which includes; price for uniforms, pencils, transportation, and opportunity forgone among others. Yet, the schools' management have to charge certain levies as user-charges to aid in the running of the school, such as; sports levy, hostel levy, utility levy, Parents Teachers Association (PTA) levies to support in school development. The analogy is that; government have declared that it cannot solely fund the educational sector and it welcomes the participation of private sector and the community (FME, 2014).

School management has the task of sensitizing the populace on the need to contribute financially towards the provision of education. Nigerian government cannot afford to sponsor education alone. The incapability is evident in the annual budget of education whereby government cannot meet the required allocation of the minimum benchmark of $26 \%$ of its annual budget to education as declared by United Nations Educational Scientific and Cultural Organization (UNESCO). For example, in 2010, the annual budget was 4.07 Trillion and the annual allocation to education was $249.08(6.42 \%)$, in 2015, annual budget was 4.40 Trillion, allocation was $392.20 \quad$ (8.9\%) (Olorundare, 2011). This is far in a shortfall from the $26 \%$ prescription by the UNESCO. The fundamental challenge is that people who cannot afford to pay for user-charges due to poverty, other socio-economic and socio-cultural challenges, drop-out of school or cannot even have the opportunity to access education. For instance, over 10.5 Million school-age children are out of school in Nigeria (UNESCO, 2016). Educational Financing in Nigeria has been adjudged poor as compared to other African countries thus; Botswana $19.0 \%$, Kenya $23.0 \%$, Morocco, $17.7 \%$, Swaziland $24.6 \%$, South Africa, $25.8 \%$, Burkina Faso, $16.8 \%$, Lesotho, $17.0 \%$, Cote-dViore, 30.0\%, and Ghana, 31.0\% (Adamu, 2017; UNESCO, 2016). Principals' managerial skills can promote the provision of funds in schools through appropriate funding options. Efforts to appeal for funds from various stakeholders require tactical skills that are obvious to convince donors about the needs of the school.

Funding options are therefore sourced for to promote the implementation of educational policies. It involves raising money as endowments, bank loans, soliciting for contributions through sponsorship among others to bridge the gap between money allocated for education and the shortfall to meet the required resources for achievement of quality goals. Educational financing is the process of sourcing and allocating money and resources in managing public educational objectives. It involves the process by which tax revenues and other resources are derived for the establishment and operation of educational institutions as well as the process by which these resources are allocated to institutions in different geographical areas. The quality service delivery of education is one of the key building blocks in the educational system. The service delivery requires substantial human and material resources and sustained quality assurance measures which is spear headed by the management (Adepoju \& Oluchukwu, 2011).

Consequently, the absence of basic facilities for education delivery service can result to poor students' performance. Apparently, the public outcry about poor quality of junior secondary school graduates is quite alarming. Some of them cannot construct good sentences in English Language. The 
spill over in Basic Education Certificate Examination (BECE) is significant in the poor performance of students in Senior School Certificate Examination (SSCE). Lawrence (2012) pathetically observes that about $93 \%$ of junior secondary students III in any given year do not pass well to enter senior secondary one. Olorundare (2011) noted that only about $20 \%$ of the candidates passed at acceptable credit level out of thousands of students who sat for the Basic Education Certificate Examination (BECE). In addition, Ashrofbin (2017) found out that schools with adequate physical facilities which are in good condition may influence students to perform well in learning process and examination. Dilapidated school buildings and overcrowded classrooms among others contribute to poor academic performance. Teachers at all levels of education are poorly treated especially in terms of remuneration. This is quite evident in incessant strike actions by teachers at different levels.

Corruption in the educational sector is another element of funding challenges. It is an act of perversion and injustice of failing to do the right and just. Adida and Asindi (2020) ranked Nigeria $144^{\text {th }}$ out of 180 countries in terms of corruption. The corrupt attitudes of financial managers are great set back to the attainment of educational goals. Management of secondary schools is an effective organization, coordination and direction of educational activities to achieve set goals. It requires accountability and transparency in transactions and manipulation of resources. The management behaviour of the person in leadership embraces the vital functions of planning, organizing, directing, controlling, coordinating and evaluating activities to influence quality accountability (Mgbolide, 2004).

From the fore-going, the educational system requires a reengineering effort to overcome the challenges that threaten quality achievement. To guarantee the responsiveness of quality funding options in secondary schools, there is need for the use of quality management skills to overhaul educational financing to promote effectiveness and efficiency in the system. It is clear that the educational system is underfunded as a result of poor management and has resulted to lack of resources for quality teaching and learning in schools. Consequently, junior secondary school students' performance is lower than expected. It is against this background that this study will examine funding options in the management of junior secondary schools in Kaduna State.

\section{STATEMENT OF THE PROBLEM}

Personal observation has shown that one of the major crises facing the educational system in Nigeria is inadequate funding. It is evident that most of the deficits in both human and material resources stem from funding lapses. The scarce resources available seem to be mismanaged through corruption and administrative flaws. Management of funds deals with the provision, custody, and disbursements of financial resources. A cursory look will show the uneven distribution of resources whereby in certain areas are dilapidated buildings, shortage of classrooms where students learn under the trees or lack the furniture to sit on. This might have informed the poor academic performance of students in BECE. The policy of UBE which states the provision of free and compulsory education seems deceptive as government cannot provide all the requirements in the provision of education. Consumers of education have to incur some prices in cash and opportunity forgone. Consequently, those who cannot afford are out of school. Appropriate use of funding options in the management of schools might promote increase in finance to available quality human and material resources for standard teaching and learning.

Despite efforts made by the Federal Government to sensitize people on participation in funding the educational system the educational system still surfers financial deficits in Nigeria. Therefore, this study aims at answering the major question; what is the extent of funding option in the 
management of junior secondary schools in Nigeria?

\section{PURPOSE OF THE STUDY}

The study is aimed at examining the extent of funding options in the management of junior secondary schools in Kaduna State. The specific objectives include:

1. to find out the funding options in junior secondary schools in Kaduna State

2. to determine the management skills used for raising fund in the management of junior secondary schools in Kaduna state.

3. to ascertain the contributions of community in funding junior secondary schools in Kaduna State.

4. to determine the influence of managerial skills of principals on funding options in junior secondary schools in Kaduna State

\section{RESEARCH QUESTIONS}

1. What are the funding options in junior secondary schools in Kaduna State?

2. What are the management skills used for raising fund in the management of junior secondary schools in Kaduna State?

3. What is the contribution of community in the funding of junior secondary schools in Kaduna State?

\section{HYPOTHESIS}

1. There is no significant mean difference between principals' managerial skills and funding options in junior secondary schools in Kaduna State.

\section{METHODOLOGY}

\section{Research Design}

The study adopted the crosssectional survey design. This is considered appropriate as it aids in identifying the characteristics of the phenomena and describe findings to serve as a representative of the entire population (Ugodulunwa, 2008). It is used to examine funding options in the management of junior secondary schools in Kaduna State.

\section{Population and Sample}

The population of the study comprised the 411 principals of junior secondary in Kaduna State as at 2019. The sample of the study was made up of 111 principals of junior secondary schools in Kaduna state. The simple random sampling technique was used to obtain the sample using the lottery method. This was found appropriate as it provided equal chances of selection from the population.

\section{Instrument for Data Collection}

A 20 item Likert type scale questionnaire tagged: Funding Options Management Questionnaire (FOMQ) developed by the researcher was used to collect data. The questionnaire was validated by two experts in the area of Educational Administration and planning in University of Jos. They scrutinized and identified the errors which were corrected and confirmed valid for the study. The reliability of the instrument was confirmed to be 0.81 which was rated reliable for the study (Cohen \& Manion, 2001).

\section{Procedure for Data Collection}

The face-to-face method of direct delivery was used for data collection. The researcher personally visited the schools and sought for permission from the school principals to allow for data gathering. The confidentiality of any information gathered was stressed and observed. The instrument FOMQ was administered to the respondents and returned to collect after one day. A 100 percent return of questionnaire was obtained.

\section{Procedure for Data Analysis}

The mean and standard deviation were used to answer research questions while the t-test of independence was used to test the hypothesis. The criterion mean for taking decision was 2.5. If the mean confirmed is lesser than the criterion mean, it means it is at the 
disagreed level, while the mean equal to or greater than the criterion mean is at the agreed level. The decision rule for hypothesis depends on: if the $P$ value is less than 0.05 level, the null hypothesis was rejected, but when the $P$ value is greater than 0.05 level of significance, the null hypothesis was accepted.

\section{RESULTS}

Research Question 1: What are the funding options in Junior Secondary Schools in Kaduna State?

Table 1: Results of the Analysis on Funding Options in Junior Secondary Schools in Kaduna State

\begin{tabular}{lllll}
\hline S/N & Statement & X & SD & Decision \\
\hline 1. & Students pay tuition fees in this schools & 1.75 & 0.61 & Disagreed \\
2. & Students pay Parents Teachers Association (PTA) levies & 3.04 & 0.90 & Agree \\
3. & Students pay utility charges for sports in schools & 2.89 & 0.75 & Agree \\
4. & Students pay school-based management committee & 2.65 & 0.51 & Agree \\
& (SBMC) charges & & & \\
5. & Students pay extra-curricular levies in schools & 3.90 & 0.88 & Agree \\
6. & School sells farm produce from agriculture practical & 2.83 & 0.65 & Agree \\
7. & Students sell the invented products made by students & 2.75 & 0.71 & Agree \\
8. & The alumni of this schools assist the schools financially & 3.09 & 0.46 & Agree \\
9. & Schools seek for grants from international agencies & 2.33 & 0.97 & Disagree \\
10. & Schools seek for assistance from internal agency & 2.51 & 0.72 & Agree \\
\hline
\end{tabular}

\section{Criterion mean $=\mathbf{2 . 5 0}$}

The results of the analysis from table one shows that item $2,3,4,5,6$, 7,8 and 10 were agreed. This reveals that the funding options for Junior Secondary Schools in the study area are Parents Teachers Association levies, utility charges for sports, school-based management charges, examination levies, and sales from agricultural practical, alumni assistance sources. While item 1 and 9 were disagreed upon.
This means that tuition fees and grant from international agencies are not options for funding in Junior Secondary Schools in the study area.

Research Question 2: What are the management skills used in the management of Junior Secondary Schools in Kaduna State?

\section{Table 2: The Results of the Analysis on Management Skills Used to Raise Fund in Junior Secondary Schools}

\begin{tabular}{lllll}
\hline S/N & STATEMENT & X & SD & DECISION \\
\hline 1. & $\begin{array}{l}\text { There is cordial relationship between the school and the } \\
\text { community for financial support }\end{array}$ & 3.27 & 0.57 & Agreed \\
2. $\quad \begin{array}{l}\text { It is difficult to communicate with the international } \\
\text { agency for secondary school financial support }\end{array}$ & 2.96 & 0.46 & Agreed \\
3. $\quad \begin{array}{l}\text { Planning for appeal fund fails due to lack of money in the } \\
\text { school }\end{array}$ & 3.17 & 0.37 & Agreed \\
4. $\quad \begin{array}{l}\text { The coordination to harmonize efforts to raise fund seems } \\
\text { impossible due to lack of resources in the school }\end{array}$ & 3.18 & 0.45 & Agreed \\
5. $\quad \begin{array}{l}\text { Teachers are motivated to promote innovation for fund } \\
\text { raising in the school }\end{array}$ & 2.17 & 1.11 & Disagreed \\
6. $\quad \begin{array}{l}\text { The organization for commercial activity in the school has } \\
\text { been hampered due to lack of interest }\end{array}$ & 3.46 & 0.04 & Agreed \\
\hline
\end{tabular}




\section{Criterion Mean $=2.50$}

The results of the analysis in table two shows that items $1,2,3,4$ and 6 are agreed upon which implies that managerial skills used in Junior Secondary Schools include, cordial relationship between the school and the community, difficult in communicating with international organisation, planning appeal fund fails due to lack of funds, coordinating to harmonize efforts and organization for commercial activity. While item 5 was disagreed, this shows

that teachers are not motivated to promote innovation. This implies that most of the managerial skills are utilized in the management of Junior Secondary Schools in the study area but, fail to search for external financial assistance.

Research Question 3: What is the contribution of community in funding Junior Secondary Schools in Kaduna State?

Table 3: The Results of the Analysis on contributions of Community in Funding of Junior Secondary School

\begin{tabular}{lllll}
\hline S/N Statement & $X$ & SD & Decision
\end{tabular}

\begin{tabular}{lllll}
\hline 1. & The community participates in funding schools & 3.71 & 0.511 & Agreed \\
2. & The community supports in building classrooms & 3.75 & 0.43 & Agreed \\
3. & The community engages in levying people to support & 3.57 & 0.54 & Agreed \\
& & & & \\
the schools & $\begin{array}{l}\text { Schools appeal for fund from illustrious people in the } \\
\text { community }\end{array}$ & 3.71 & 0.511 & Agreed
\end{tabular}

\section{Criterion Mean 2.5}

The results of the analysis in table three show that all the items were accepted. This implies that the community participate in funding Junior Secondary Schools in Kaduna State through the construction of classrooms, levying people and appealing to its illustrious people. This shows that the community contributes a critical role in funding Junior Secondary Schools in the study area.

Hypothesis 1: There is no significant mean difference between principals' managerial skills and funding options in Junior Secondary Schools in Kaduna State.

Table 4: The Results of the t-test Analysis on Principals' Managerial Skills and Funding Options

\begin{tabular}{lllllll}
\hline Category & N & X & SD & df & P-Value & Sig \\
\hline Funding Options & 111 & 26.96 & 5.20 & 220 & 0.000 & 0.05 \\
Managerial Skills & 111 & 18.23 & 1.27 & & & \\
\hline
\end{tabular}

$\mathrm{P} \geq 0.05$

The result of the analysis in table four shows that the P-value of 0.000 is less than the significant level of 0.05 . The null hypothesis is rejected. This implies that there is a significant difference in principals' managerial skills and the funding options. 


\section{DISCUSSIONS}

The study on funding options in the management of junior secondary schools in Kaduna State revealed certain issues that could add to the body of knowledge. It was confirmed that students pay PTA levies, utility charges for sports, SBMC charges, extracurricular charges, sale of agricultural products and products invented by students, and appeal from alumni to raise funds for utilization in the school. It was however revealed that students are not charged tuition fees, and the schools do not make effort to raise fund from international agencies but seek for assistance from internal agencies. This finding matches the idea of Okontoni (2014) who identified funding options to be regular contributions from communities, states, churches, school authorities, and other external bodies. But the implication of this finding is that the schools depend mostly on their internal sources such as, levies and other user charges without going extra mile to source for money and grants from international organizations. The irony is that people who cannot pay the levies and user charges due to poverty can easily dropout of school, which is adjudged unjust to any schoolgoing age child that needs to be in school. When schools link with international agencies through research or other networks, it is possible to raise fund for the development of the schools.

Findings revealed the managerial skills used to raise fund in junior secondary schools in Kaduna State to include; communication, cordial relationships with communities, planning for appeal fund, coordination to harmonize efforts, and organization for commercial activities which is inadequate for lack of interest and teachers are not motivated for innovation to raise fund for the school. This finding collaborates the ideas of Mgbolide (2004) and Emenalo (2009) who indentified some types of managerial skills in any field of management that can influence goal achievement such as, related skill, technical skills and human skills which involves creating harmonious working relationship with group members and build cooperative efforts. This implies that effective managerial skills can promote cooperation between stakeholders and facilitate efforts to raise fund for the school. Adequate available fund can enhance quality teaching and learning processes.

The study confirmed the contributions of community participation in funding schools to include; provision of funds, building classrooms, levy of community members to support the school, and appeals for fund from illustrious people in the community for the school development. This finding is in support of the Federal Ministty of Education (2014) on the declaration that government cannot solely fund the educational sector and it welcomes the participation of private sector and the community. This implies that the community in Kaduna State adhered to this plea and the community and private individuals support financially in the management of the schools. Yet, school leaders require the practice of the managerial skills that can promote school-community relationships through advocacy, sensitization and mobilisation for awareness and involvement of all stakeholders in funding education.

Finding of hypothesis testing confirmed the $P$ value lesser than 0.05 level of significance. Hence, there is a significant difference in principals' managerial skills and funding options in senior secondary schools in Kaduna State. This finding appears contrary with the views of Adepoju and Oluchukwu (2011) who maintained that service delivery requires substantial human and material resources and sustained quality assurance measure which is spear headed by the management. This implies that management in schools hardly concentrate on using funding options approaches to raise funds for the school. The repercussion would be deficit in resources thereby leading to low academic achievement in schools.

\section{CONCLUSION}

The study on funding options in the management of senior secondary schools in Kaduna State confirmed the 
inadequacies in school management efforts to raise funds for the schools. However, certain funding options are practiced in the schools such as; PTA levies, sales of students' agricultural products, appeal fund from the community, user-charges among others in the schools. Efforts to link with international agencies for grants were not feasible. The study reveals that the community contributes to funding of schools through building of classrooms and raising funds from illustrious people of the community to support the schools. School leaders' managerial skills needed to be improved to influence the use of funding options through both national and international agencies for the development of the schools.

\section{RECOMMENDATIONS}

Based on the findings of this study, the following recommendations are made:

1. School Administrators should be creative in connecting with internal and external agencies to raise funds for their schools through research and academic linkages to promote quality education.

2. Government should set strategies of motivating school administrators and ensure their capacity building on fund raising to facilitate creativity and innovation in their production approaches in order to compete favourably in the global market.

3. School leaders should promote school-community cordial relationships and advocate for support of funds, materials and selfless service that can facilitate a variety of funding options for the school.

4. Government should intensify public campaign to create awareness on the need for the general public to see the provision of education as the responsibility of all. This can further be intensified through capacity building of community members at grassroots level.

\section{Conflict of Interest}

There was no conflict of interest for this study.

\section{Acknowledgement}

I thank God for the blessings and opportunity to write this paper. I wish to also acknowledge the valuable contributions of the reviewers of this article and Dr. Rufus O. Adebisi who guided me in setting this work appropriately. Thank you.

\section{Disclaimer Statement}

I hereby declare that this study is the product of my own research efforts and has not been presented elsewhere for publication. All sources have been duly distinguished and appropriately acknowledged.

\section{Notes on Author}

Dr. Theresa S. Gyang is an Associate Professor in the Department of Educational Foundations, Faculty of Education, University of Jos. Her area of specialization is Educational Administration and Planning. She has published widely in both national and international journals.

Authorship and Level of Contribution Dr. Theresa S. Gyang is the only author of this article.

\section{REFERENCES}

Adamu, A. (2017). Illiteracy rate in Nigeria. Retrieved from http://www. vanguarddngr.com

Adepoju, T. L., \& Oluchukwu, E. E. (2011). A study of secondary school students' academic performance at the senior school certificate examination and implications for educational planning and policy in Nigeria. An International Multi- Disciplinary Journal, Ethiopia, 5(6), 314333.

Adida, F. A., \& Asinde, A. A. (2020). The journey of education in Nigeria within six decades of Nationhood policies and programmes. Lafia Journal of Education, 1(3), 167-178. 
Ashrofbin, Z. (2017). The school facilities towards the improvement of students' academic

achievemn: A case studysecondary school in Klang. Journal of Modern Education Review, $7(9), 58-71$.

Cohen, I., \& Manion, L. (2001). Research methods in education. Routledge.

Emenalo, F. C. (2009). Quality management in education. In J. B. Babalola and A.O. Ayeni (Eds), Educational management: theories and tasks (pp. 741-759). Macmillan Nigeria Publishers Limited.

Federal Ministry of Education (2014). National policy on education. NERDC

Lawrence, A. S. A. (2012). School environment and academic achievement of standard four students. Journal of educational and Instructional Studies in the World, 2 (3), 210- 215.

Mgodile, R. O. (2004). Educational Administration and supervisor associateship constitutive in education service. Heinemann Education Books Nigeria Limited.

Okontoni, C. A. (2014). Management of conflict in secondary school in Osun State. Master Dissertation, Obafemi Awolowo University IleIfe.

Olorundare, T. (2011). School or food? The cost of public education. Indicator, 30(2), 8- 15.

Ugodulunwa, C. A. (2008). Fundamentals of educational measurement and evaluation. Fab Anieh.

UNESCO. (2016). Education 2030. Incheon declaration and framework for action. Towards inclusive and equitable quality education and lifelong learning for all.

UNESCO.

www.uis.unesco.org/Education/Do cuments/ incheon-framework-foraction-en.pdf. 